\title{
HIGHER EDUCATION, GLOBALISATION AND THE KNOWLEDGE ECONOMY:
}

\author{
Reclaiming the Cultural Mission ${ }^{1}$
}

\begin{abstract}
The liberal university belongs to the past. The inescapable question now is whether the university will become the locus of integration or of confrontation. In both cases grave dangers may threaten the creation of new knowledge.

Alain Touraine, 1974:13.

Knowledge is and will be produced in order to be sold, it is and will be consumed in order to be valorised in a new production: in both cases, the goal is exchange.
\end{abstract}

Jean-François Lyotard, 1984: 4.

\section{INTRODUCTION}

To say that the university is in crisis is to echo the thoughts and sentiments of a generation of post-war commentators. The word 'crisis', accordingly, has almost lost the theoretical purchase it once had and slipped into a kind of rhetoric that is now consistently invoked by writers and scholars of all political persuasions. The term crisis was used to refer to the crisis of governance of the university following the student unrest and resistance of the late 1960s. Analysis of the demands made by the student movement pointed to the need for a greater democratisation of the university. It revealed the elitist functions of the university based upon the myths of 'pure inquiry' and 'objective knowledge' which operated, ideologically, to screen out different cultural and gender values that determine both what counts as knowledge and legitimate ways of pursuing it.

The term was used again during the 1970s to refer to the decline of the humanities. This was a period when increasing numbers of students in western universities opted for science and technology and 
the first real pressures for universities to become more vocationally oriented began to be felt. The general shift to the Right that took place in global politics during the 1980s and the emergence of a set of policies based upon neo-liberal principles expressing both the failure of 'big' government and a commitment to free-market solutions, became associated with a double notion of 'crisis'. The first was linked to the university's survival: it was linked to problems of funding and was seen, above all, as a fiscal crisis -- one of external legitimation and principally a crisis focusing upon the continued financial viability of the institution. The second centred on the curriculum and the crisis of the humanities. In the American academy especially, this notion of crisis had been manufactured by those dedicated to a conservative cultural project.

The transformation of higher education in Anglophone countries from a universal welfare entitlement into a private investment in 'human capital' established a similar pattern shared by a number of OECD countries. First, a transparent alignment of the university system to reflect the needs of an emerging 'post-industrial' economy, with increasing demands for highly trained, multi-skilled, tertiaryeducated workers. Second, the introduction of new forms of corporate managerialism and the emulation of private sector management styles; the coporatization of the university system -- an emphasis on so-called 'clear accountability structures' including the attempted simplification of goals or purposes, and the institution of new forms of delegated authority. Third, the introduction of corporate or strategic planning and the move to institute a form of 'ownership monitoring' in order, allegedly, to reduce the financial risk of the State. Fourth, under neo-liberalism, there was an attack on faculty representation in university governance and the general attempt to discredit democratic forms of university governance on 'efficiency' grounds. Finally, the introduction of user-charges, student loans, and the creeping privatisation of the system as a whole took place to varying degrees in countries like New Zealand, Australia, Canada and the United Kingdom.

The writing was on the wall in the 1980s when calls were made for a reappraisal of the university institution. Thus, for instance, the OECD Intergovernmental Conference on 'Policies for Higher 
Education' in 1983 referred not only to 'the crisis of performance' but, more fundamentally, pointed to 'an internal crisis of purpose'. The OCED publication, Universities Under Scrutiny (1987: 3) began by questioning 'the very purposes and functions of higher education in post-industrialised societies'. The OECD Secretariat emphasised the mismatch between the university's self-definition and external expectations and suggested a set of policies that, at one and the same time, promoted a greater vocationalism and sense of 'appliedness', and a greater focus on efficiency, productivity and accountability.

The 'massification' of higher education within OECD countries also involved the implementation of new financial models, which determine the manner and amount of institutional funding. This policy move was predicated on the basis of an official recognition that there is an alleged need to reduce the burden on governments to act as sole providers and that private sector had an increasing role to play either directly or in partnership with public institutions. In some countries it also indicated that arguments that education constitutes a private good had found favour with politicians who often believed that competition for funds increase institutional efficiency and responsiveness. Experimentation with alternative institutional funding mechanisms in OECD countries over the past couple of decades appear to follow a similar pattern: adoption and increased sophistication of institutional formulae-founding; greater financial autonomy and market freedom for institutions; an increasing proportion of income from student fees; sharper distinction between funding of research and of teaching; an increased proportion of public funding to be 'bid for' by the institutions; and the encouragement of a diversification of funding sources with the promotion of partnerships with business. Even with the diversification of funding sources, universities have struggled to cope financially and many have kept student fees relatively low only by drawing upon their reserves. The 1990s became an era of managerial restructuring and closure for some departments, faculties and institutions especially as the spectacular growth in participation experienced in the last few decades forced institutions not only to compete with each other in the market for student places but also 
absorb the cost of providing extra, unfunded, student places, at declining levels of State funding.

The result has been, as the UK White Paper, The Future of Higher Education (see: http://www.dfes.gov.uk/higher education/hestrategy/) acknowledges, serious under-funding. The White Paper records, for instance, that funding per student fell 36\% between 1989 and 1997; that many of the UK's economic competitors invest more in higher education; and that the investment backlog in teaching and research is estimated at 8 billion pounds. The White Paper suggests a three-pronged long-term investment and reform strategy designed to promote research, knowledge transfer and the quality of teaching with the goals of harnessing knowledge to wealth creation and increasing participation in higher education (from the current $43 \%$ to $50 \%$ ). While there is a positive recognition of the under-funding crisis and a promised increase in spending on research of 1.25 billion (compared to 2002-03) it is delayed to 200506 , there is also a greater pragmatic emphasis on creating and encouraging a greater 'knowledge exchange' with business and regional development agencies. ${ }^{2}$ The discourse of 'excellence' characterises the document, a kind of empty signifier. The dis-ease, the diagnosis and the remedy are now part of an on-going policy mantra in higher education designed to come to terms with the impact of globalisation.

In The University in Ruins Bill Readings (1996:1) suggests that there is a general uncertainty as to the role of the university: university teaching staff are being proletarianized; the number of part-term contracts have increased; the production of knowledge is uncertain. The crisis of the humanities would not in itself be significant, he maintains, were it not accompanied by an external legitimation crisis. His analysis is that the role of the university has shifted as the forces of globalisation have become more evident:

the University is becoming a different institution, one that is no longer linked to the destiny of the nation-state by virtue of its role as producer, protector, and inculcator of an idea of national culture. The process of economic globalisation brings with it the relative decline of the nation-state as the prime instance of the reproduction of capital around the world. For its part, the 
University is becoming a transnational bureaucratic corporation, either tied to transnational instances of government such as the European Union or functioning independently, by analogy with a transnational corporation (Readings, 1996: 3).

The emergence of the concept of culture, he suggests, should be understood as a particular way of dealing with the tensions that arose between the University and the State, as essentially modern institutions. When he writes of the University he is referring to the German model that Humboldt instituted at the University of Berlin. The notion of culture as the central legitimating idea of the modern University has come to the end of its usefulness and, accordingly, 'the story of liberal education has lost its organizing center' (Readings, 1996:10). The overall nature of the University has become corporate rather than cultural. University administrators, government officials and policy experts increasingly talk of the University's mission in terms of 'excellence' rather than 'culture', yet 'excellence' is non-ideological, Readings (1996:13) argues, (though not unpolitical) in the sense that 'what gets taught or researched is less important than the fact that it be excellently taught or researched'.

My argument in this chapter will be that the idea of modern university, historically speaking, is to be identified with a set of founding discourses initiated by Kant, the Humboldt brothers, John Newman and others. Taking my lead from Bill Readings I shall argue that three ideas of the university dominate the modern era: the Kantian idea of reason; the Humboldtian idea of culture, and; the techno-bureaucratic idea of excellence.

Readings (1993: 163) summarises the history of the modern University in terms of three overarching ideas:

The history of the modern University can be crudely summarised by saying that the modern University has had three Ideas, the Kantian idea of reason, the Humboldtian notion of culture, and now the technological idea of excellence. The distinguishing feature of the last . . . is that it lacks all referentiality -- it is the simulacrum of the Idea of a University . 
. . in the Kantian University [the president's] function is the purely disciplinary one of making decisive judgements in interfaculty conflicts on the grounds of reason alone. In the University founded on culture, the president incarnates a pandisciplinary ideal of a general cultural orientation. . . In the contemporary University, however, a president is a bureaucratic administrator. . . From judge to synthesiser to executive.

One might argue that the founding discourses of the modern university have been permanently fractured and that under the combined pressures of globalization, managerialism and marketization, it is no longer possible to talk of the idea of modern university, of an institution both regulated and unified through the force of a single idea. The idea of the modern university based on Kant, Humboldt or Newman has become historical in the sense that the techno-bureaucratic idea of excellence has instituted an historical break or rupture with the modern. In other words, the university has become 'post-historical'. I hasten to add that my use of the term 'post-historical' is not meant to suggest an 'end of history' or 'the end of ideology' thesis: these are the melodramatic tropes of Hegelians who believe that history is motored by a dialectical struggle of opposing forces that ends when one side prevails over the other. Thus, right Hegelians like Francis Fukuyama, believe that the collapse of communism after 1989 and the end of the Cold War signals the triumph of capitalism, and, therefore, the 'end of history', in much the same way that Marxists, of at least one persuasion, believed that history ended with establishment of the 'classless' society and the rule of the proletariat. My use of 'post-historical', however, is meant to signify an 'end of modernity' and, consequently, an institutional transformation of the modern university.

In the first part of this chapter-'The Modern University'--I trace Readings' argument concerning the three dominant ideas or grand narratives of the university, in terms first crystallized by the French philosopher, Jean-François Lyotard who died in April 1998. ${ }^{3}$ In the second section-'The Post-Historical University'-- I provide some analysis of the neo-liberal, briefly identifying two forms of the 'posthistorical' university as they have been defined in the Dearing report 
(United Kingdom) and the West report (Australia). In the third part, I examine the university in the 'knowledge economy'. Finally, I revisit Readings (1996: 119), who at one point was going to title his book 'The Post-historical University'. He asks: 'How are we to re-imagine the university, once its guiding idea of culture has ceased to have an essential function?' He suggests that we must recognise that the university is in ruins and he asks us to ponder the question of what it means to dwell in the ruins ${ }^{4}$ without falling back on romance or nostalgia. I discuss his answer to this question in critical but sympathetic terms and propose a different answer to the question, an answer that depends upon a reconstruction of the three Ideas of the modern university understood in terms of what I call 'knowledge cultures'.

\section{THE MODERN ('HISTORICAL’) UNIVERSITY}

In his book The University in Ruins Readings (1996) suggests that with the advent of globalization and the decline of the nation state as one of the major organizing principles of economic and cultural development both the Kantian and Humboldtian ideas have become problematic. Universities now function as one more bureaucratic subsystem among others harnessed in the service of national competitiveness in the global economy. In the age of global capitalism universities have been reduced to a technical ideal of performance within a contemporary discourse of 'excellence'.

The university becomes modern when all of its activities are organized in terms of a single regulatory and unifying idea: the 'uni' of the 'versity', so to speak. As Timothy Bahti (1987: 438) argues:

Bahti indicates that whereas the seventeenth century had been heyday for the European academies of sciences, the eighteenth had been the low point for German universities: student rioting and drunkenness, dropping enrolments and little relationship between subjects taught and vocations. In the last decade of the eighteenth century there was talk of abolishing the university altogether, allowing the academies of sciences and the new practical vocational schools to take its place. And then in 1810, the University of Berlin was founded. In the intervening years 
were the reorganization of the Prussian bureaucracy following the defeat of Prussia by Napoleon and, as Bahti (1987: 439) points out, 'the philosophical writings on and for the university, from Kant and Schelling and then from Fichte, Schleiermacher, and Humboldt'.

For Kant it was the idea of reason, which provided an organizing principle for the disciplines, with 'philosophy' as its home. Reason is the founding principle of the Kantian university: it confers universality upon the institution and, thereby, ushers in modernity. Reason, as the immanent unifying principle of the Kantian university, displaces the Aristotelian order of disciplines of the medieval university based on the seven liberal arts, (divided into the trivium [grammar, rhetoric and knowledge] and the quadrivium [arithmetic, geometry, astronomy, and music]), to substitute a quasiindustrial arrangement of the faculties. The three higher faculties -theology, law, and medicine, have a content, whereas the lower faculty, philosophy, does not. It has no content apart from the free exercise of reason and the self-critical and self-legislating exercise of reason, embodied in the philosophy faculty, controls the higher faculties, checking their credentials and credibility, and thereby establishing autonomy for the university as a whole. In The Conflict of the Faculties Kant (1979: 23, orig. 1798) writes:

It was not a bad idea, whoever first conceived and proposed a public means for treating the sum of knowledge (and properly the heads who devote themselves to it), in a quasi industrial manner, with a division of labour where, for so many fields as there may be of knowledge, so many public teachers would be allotted, professors being trustees, forming together a kind of common scientific entity, called a university (or high school) and having autonomy (for only scholars can pass judgement on scholars as such); and, thanks to its faculties (various small societies where university teachers are ranged, in keeping with the variety of the main branches of knowledge), the university would be authorised to admit, on the one hand, studentapprentices from the lower schools aspiring to its level, and to 
grant, on the other hand -- after prior examination, and on its own authority -- to teachers who are 'free' (not drawn from the members themselves) and called 'Doctors', a universally recognised rank (conferring upon them a degree) -- in short, creating them.

Reading (1996: 59) argues that there is, in Kant, a problem or paradox that haunts the constitution of the modern university: how to institutionalise reason's autonomy, how to unify reason and the state, institution and autonomy? Kant attempts to reconcile the conflict through the republican subject, the universal subject of humanity, who incarnates this conflict. Thus, while it is one of the functions of the university to produce technicians or men of affairs for the state, the state must protect the university to ensure the rule of reason in public life. Philosophy, as the tribunal of reason, must protect the university from the abuse of power from the state and must act to distinguish legitimate from illegitimate conflict, that is, from the arbitrary exercise of authority.

The legitimacy of the state in Germany derives from the notion of ethnicity, as opposed to the French focus on the idea of humanity, more generally. On this basis, once the idea of reason is replaced with the idea of a national culture, the university is pressed into service of the state. Culture, like reason, serves as a unifying idea for the university, tying it to the nation-state. Readings argues that Humboldt's project for the foundation of the University of Berlin is decisive for the modern university up until the present day. For the German idealists, from Schiller through Schleiermacher to Fichte and Humboldt, the unity of knowledge and culture, exemplified best in the organicity of ancient Greek culture, has been splintered and lost. It can be reintegrated into a unified cultural science through Bildung, the formation and cultivation of moral subjects. Readings (1996: 15) argues:

Under the rubric of culture, the University is assigned the dual task of research and teaching, respectively the production and inculcation of national self-knowledge. As such, it becomes the institution charged with watching over the spiritual life of the 
CHAPTER 11

people of the rational state, reconciling ethnic tradition and statist rationality.

The German idealist's notion of culture is given a literary turn by the British and Americans. In particular, the English, under John Newman and Matthew Arnold, continue the efforts of Humboldt by substituting literature for philosophy as the central discipline of the university, and, therefore, also of national culture. The possibility of a unified national culture is defined explicitly in terms of the study of a tradition of national literature (or canon, as in the case of the United States).

Literature and the function of criticism is entrusted with a social mission in the Anglo-American university. In England, the idea of culture gets its purchase in opposition to science and technology, partly as a result of the threat posed by industrialisation and mass civilisation. Newman gives us a 'liberal education' as the proper function of the university, which educates its charges to be gentlemen, not through the study of philosophy, but through the study of literature. In 'Literature: A Lecture in the School of Philosophy and Letters’ delivered in 1858, Newman (1968: 201-21) 'explicitly positions as the site of the development of both an idea of the nation and the study of literature as the means of training national subjects' (Readings, 1966: 76). Newman (1968: 230) suggests that 'A literature, when it is formed, is a national and historical fact; it is a matter of the past and present, and can be as little ignored as the present, as little undone as the past'. National language and literature defines the character of 'every great people', and Newman speaks of the classics of a national literature by which he means 'those authors who have had the foremost place in exemplifying the powers and conducting the development of its language' (p. 240).

Readings (1996: 78) argues that 'For Arnold, as for Eliot and Leavis after him, Shakespeare occupies the position that the German Idealists ascribed to the Greeks: that of immediately representing an organic community to itself in a living language'. In 'The Idea of a University' F. R. Leavis proposes that all study should be centred in the study of literature, centred in the seventeenth century and based on Shakespeare as the natural origin of culture. Leavis believes that 
the University of Culture can provide the lost centre and heal the split between the organic culture and mass civilization.

The grand narrative of the university, centred on the cultural production of a liberal, reasoning, citizen subject, in the wake of globalisation, is no longer credible. 'The University ... no longer participates in the historical project for humanity that was the legacy of the Enlightenment: the historical project of culture' (Readings, 1996: 5). The movement from cultural élite formation to the post-war massification of higher education has subjected the universalism of liberal education to criticism of its privilege based on the lines of class, gender and ethnicity. It is precisely at this point that the link between the university and the nation-state breaks down and the discourse of excellence gains a purchase. The University of Excellence replaces the University of Culture. As Readings (1996: 14) argues:

The economics of globalisation mean that the University is no longer called upon to train citizen subjects, while the politics of the end of the cold war mean that the university is no longer called upon to uphold national prestige by producing and legitimating national culture.

Readings suggests that excellence has become the last unifying principle of the modern university. When Ministry policy analysts or university administrators talked about excellence, unwittingly they bracket the question of value in favor of measurement and substitute accounting solutions for questions of accountability (Readings, 1996: 119). As an integrating principle excellence has the advantage of being entirely meaningless: it is non-referential. It signifies the corporate bureaucratization of the university. Universities have become sites for the development of 'human resources'. Guided by mission statements and strategic plans, performance output is measured TQM assures quality outcomes. Readings (1996: 12) remarks:

University mission statements, like their publicity brochures, share two distinctive features nowadays. On the one hand, they all claim that theirs is a unique educational institution. On the 
CHAPTER 11

other hand, they all go on to describe this uniqueness in exactly the same way.

He goes on to tell the true story about of how Cornell University Parking services received an award recently for 'excellence in parking'. I shan't labor the point any further: the discourse of excellence is essentially contentless. It does not enable us to make judgments of value or purpose; it does not help us to answer questions of what, how or why we should teach or research; it can provide us with no direction but serves only to maintain and monitor the system in the 'audit society'.

\section{THE 'POST-HISTORICAL’ UNIVERSITY}

Anyone with a passing familiarity with Readings' thesis as I have presented it must recognize the traces of Jean-François Lyotard's influence. ${ }^{5}$ His The Postmodern Condition: A Report on Knowledge (1984) originally published in Paris in 1979, became an instant cause célèbre because Lyotard analysed the status of knowledge, science and the university in way that many critics believed signalled an epochal break not only with the so-called 'modern era' but also with various traditionally 'modern' ways of viewing the world. It was written, Lyotard (1984: xxv) asserts, 'at this very Postmodern moment that finds the University nearing what may be its end.'

In The Postmodern Condition Jean-François Lyotard was concerned with grand narratives which had grown out of the Enlightenment and had come to mark modernity. In The Postmodern Explained to Children Lyotard (1992: 29) mentions: 'the progressive emancipation of reason and freedom, the progressive or catastrophic emancipation of labour ..., the enrichment of all through the progress of capitalist techno-science, and even ... the salvation of creatures through the conversion of souls to the Christian narrative of martyred love.' Grand narratives are the stories that cultures tell themselves about their own practices and beliefs in order to legitimate them. They function as a unified single story that purports to legitimate or found a set of practices, a cultural self-image, a discourse or an institution. ${ }^{6}$ 
Lyotard holds that capitalist renewal after the 1930s and the postwar upsurge of technology has led to a 'crisis' of scientific knowledge and to an internal erosion of the very prospect of legitimation. He locates the seeds of such 'delegitimation' in the decline of the legitimating power of the grand narratives of the nineteenth century. ${ }^{7}$ In particular, the process of European cultural disintegration ${ }^{8}$ is symbolised most clearly by the end of philosophy as the universal meta-language able to underwrite all claims to knowledge and, thereby, to unify the rest of culture.

Since the late 1970s neo-liberalism has become the dominant grand narrative. (The publication of Lyotard's The Postmodern Condition coincided with the election to power of Margaret Thatcher's Conservative Government in Britain.) A particular variant revitalises the master discourse of neo-classical economic liberalism and advances it as a basis for a global reconstruction of society. A form of economic reason encapsulated in the notion of homo economicus, with its abstract and universalist assumptions of individuality, rationality and self-interest, has captured the policy agendas of Western countries. Part of its innovation has been the way in which the neo-liberal grand narrative has successfully extended the principle of self-interest into the status of a paradigm for understanding politics itself, and, purportedly, all behaviour and human action. In the realm of higher education policy at every opportunity the market has been substituted for the state: students are now 'customers' or 'clients' and teachers are 'providers'. The notion of vouchers is suggested as a universal panacea to problems of funding and quality. The teaching/learning relation has been reduced to an implicit contract between buyer and seller. As Lyotard argued prophetically in The Postmodern Condition not only has knowledge and research become commodified but also so have the relations of the production of knowledge in a new logic of performativity. 
CHAPTER 11

\section{THE UNIVERSITY IN THE KNOWLEDGE ECONOMY}

\section{The Post-historical University}

The crisis of the idea of the modern university has been brought about largely by changes in the nature of the capitalist system, through attempts by governments to structurally adjust their national economies to the new conditions, and by consequent shifts in the production of knowledge that leads to the de-territorialization of knowledge and intensified knowledge flows (see Delanty, 1998). The new global knowledge economy is not just a universalisation of capitalism after the collapse of actually existing communism, it also involves the rise of finance capitalism, supported by the emergence of new information and communications technologies, and a series of international agreements concerning the liberalisation of world trade.

The Dearing report recognized globalization as the major influence upon the UK economy and the labor market with strong implications for higher education. Analyzing the Dearing report it is possible to talk of the globalization of tertiary or higher education, according to three interrelated functions: the knowledge function, the labor function, and the institutional function (see Figure 1). We can talk of the primacy of the knowledge function and its globalization, which has a number of dimensions: knowledge, its production and transmission or acquisition, is still primary as it was with the idea of the modern university, but now its value is legitimated increasingly in terms of its attraction to and service to global corporations.

Knowledge is valued for its strict utility rather than as an end in itself or for its emancipatory or enlightenment effects. ${ }^{9}$ The globalization of the labor function is formulated in terms of both the production of technically skilled people to meet the needs of global corporations and the ideology of lifelong learning, where individuals can 're-equip themselves for a succession of jobs over a working lifetime'. The institutional function is summed up in the phrase 'higher education will become a global international service and tradable commodity'. The competitive survival of institutions is tied to the globalization of its organizational form (emulating private sector enterprises) and the globalization of its 'services'. With this function already a strong and 
closer alliance between global corporations and universities has developed, especially in terms of the funding of research and development, and, in some cases, the university as a global corporation with international sites for teaching and research. The latter is a trend likely to develop further with the world integration and convergence of media, telecommunications and publishing industries. The institutional form of the university depicted by Dearing, then, is one form of the post-historical university - the university as a global service corporation.

Another, even more obvious example and disturbing vision of the post-historical university is provided in a commissioned paper entitled 'Australian Higher Education in the Era of Mass Customization' by Global Alliance Limited as Appendix 11 to the West Committee's discussion paper 'Review of Higher Education Financing and Policy’ released in late November 1997. Global Alliance Limited (GAL) is a Tokyo-based investment bank established in 1995, which specializes in providing investment and corporate advisory services mainly to Japanese and Taiwanese companies, especially in relation to the information technology sector. GAL has investments on its own account in Internet service providers and related companies.

The GAL report proclaims both the end of 'the era of homogeneity' under state planning and the beginning of another era, which will be consumer-oriented, more diversified and exposed to international competition. The remnants of an era of state planning show that while costs of production are world competitive, productivity incentives are poor and capital management requires reform. The existing providers are protected in the Australian domestic market but not for too much longer.

The report identifies the following forces for change: the reducing Government fee structure, the associated shift of power to the consumer, increasing international competitive exposure and changes in the technology of production and consumption. Computers will lower costs of marketing and the provision of customer services while at the same time as promoting greater access to learning and enhancing the quality of the learning experience. Back-end systems will be automated and learning systems will increasingly apply 
computers so that courses can be delivered over the Web. The effects of these forces will lead to 'the hollowing out of the university'. The report is worth quoting at some length here:

The vertically integrated university is a product of brand image, government policy, history and historical economies of scale in support services. If government policy is no longer biased in favor of this form, and technology liberates providers from one location, then we would expect to see new forms arising such as multiple outlet vertically integrate specialist schools and web based universities ... Specialist service providers, such as testing companies and courseware developers will arise, as will superstar teachers who are not tied to any one university. Many universities will become marketing and production coordinators or systems integrators. They will no longer all be vertically integrated education version of the 1929 Ford assembly plant in Detroit (p. 12).

The overall result of the effects of these combined forces of changes are an increased segmentation of markets, an increased specialization and customization of supply of courses and an increased specialization of providers. The new university business system will take the form of one of a series of possible business models: low cost producer university; Asia middle class web university; Harvard in Australia university; world specialist school university.

Clearly, the economic importance of education has been rediscovered as fundamental to understanding the global economy (Papadopoulos, 1994: 170) and its expression in its latest phase as the knowledge economy. The OECD and the World Bank have emphasised the significance of education and training for the development of 'human resources', for upskilling and increasing the competencies of workers, and for the production of research and scientific knowledge, as keys to participation in the new global economy. Both Peter Drucker (1993) and Michael Porter (1990) emphasise the importance of knowledge -- its economics and productivity -- as the basis for national competition within the international marketplace. Lester Thurow (1996: 68) suggests 'a technological shift to an era dominated by man-made brainpower 
industries' is one of five economic tectonic plates that constitute a new game with new rules: 'Today knowledge and skills now stand alone as the only source of comparative advantage. They have become the key ingredient in the late twentieth century's location of economic activity.' Equipped with this central understanding and guided by neo-liberal theories of human capital, public choice, and new public management, Western governments have begun the process of restructuring universities, obliterating the distinction between education and training in the development of a massified system of higher education designed for the twenty-first century.

\section{Knowledge Economy, Knowledge Capitalism ${ }^{10}$}

Among the variety of discourses of the knowledge economy, those we might characterise as third generation Chicago school economics (the economics of information, of knowledge and of education) have had perhaps the greatest impact, shaping national policy constructions of the 'knowledge economy' not only in the West -USA, United Kingdom, Ireland, Australia, Canada and New Zealand - but also in the developing world, most notably, China and S. E. Asia, especially through the influence of world policy agencies. Often the link is made between technology, innovation and knowledge focusing on policies designed to assimilate the university more fully into the mode of production. The United Kingdom's White Paper Our Competitive Future (Department of Trade and Industry, 1998), for example, begins by acknowledging the fact that the World Bank's 1998 World Development Report took knowledge as its theme, citing the report as follows:

For countries in the vanguard of the world economy, the balance between knowledge and resources has shifted so far towards the former that knowledge has become perhaps the most important factor determining the standard of living... Today's most technologically advanced economies are truly knowledge-based (http://www.dti.gov.uk/comp/competitive/main.htm.)

The UK White Paper also mentions that the OECD has drawn attention to the growing importance of knowledge indicating that the 
emergence of knowledge-based economies has significant policy implications for the organisation of production and its effect on employment and skill requirements. The report suggests that already other countries including, US, Canada, Denmark and Finland, have identified the growing importance of knowledge and reflected it in their approach to economic policy.

The report emphasises so-called 'new growth theory', charting the ways in which education and technology are now viewed as central to economic growth. Neo-classical economics does not specify how knowledge accumulation occurs and, therefore, cannot acknowledge externalities. By contrast, new growth theory has highlighted the role of higher education in the creation of human capital and in the production of new knowledge (see, e.g., Solow 1956, 1994). On this basis it has explored the possibilities of education-related externalities. In short, while the evidence is far from conclusive there is a consensus emerging in economic theory that education is important for successful research activities (e.g., by producing scientists and engineers), which is, in turn, important for productivity growth, and; education creates human capital, which directly affects knowledge accumulation and therefore productivity growth (see s. $3.4 \mathrm{ff}$ 'Knowledge as the source of growth'). The report emphasises not only R\&D expenditures provide a positive contribution to productivity growth but also that education is important in explaining the growth of national income.

The White Paper emphasises that 'knowledge economy' does not mean a return to interventionist strategies of the past but neither does it mean a naïve reliance on markets. As Tony Blair expresses the role of government in the Foreword to the White Paper:

The Government must promote competition, stimulating enterprise, flexibility and innovation by opening markets. But we must also invest in British capabilities when companies alone cannot: in education, in science and in the creation of a culture of enterprise. And we must promote creative partnerships which help companies: to collaborate for competitive advantage; to promote a long term vision in a world of short term pressures; to benchmark their performance against 
the best in the world; and to forge alliances with other businesses and with employees.

In education at all levels there is a strong emphasis on the culture of enterprise and building skills of entrepreneurship which is not very different, if at all, from the policy emphases initiating by Lord Young under the Thatcher Government. There is an equal emphasis on the promotion of university-based research, on industry-education relationships especially in higher education, on workplace learning, and on building a culture of learning (including the establishment of individual learning accounts).

The United Kingdom's White Paper Our Competitive Future:

Building the Knowledge Driven Economy defines a knowledge-based economy in the following terms:

A knowledge driven economy is one in which the generation and the exploitation of knowledge has come to play the predominant part in the creation of wealth. It is not simply about pushing back the frontiers of knowledge; it is also about the more effective use and exploitation of all types of knowledge in all manner of activity

(http://www.dti.gov.uk/comp/competitive/main.htm.)

The report suggests that 'knowledge' is more than just information and it goes on to distinguish between two types of knowledge: 'codified' and 'tacit'. Codifiable knowledge can be written down and transferred easily to others whereas tacit knowledge is 'often slow to acquire and much more difficult to transfer'. The knowledge economy allegedly differs from the traditional economy with an emphasis on what I have called the 'economics of abundance', the 'annihilation of distance', the 'de-territorialisation of the state', the 'importance of local knowledge', and 'investment in human capital' (see Peters, 2001).

In the attempt to re-position and structurally adjust their national economies to take advantage of the main global trends, British, Australian, Canadian and New Zealand governments have begun to 
recognise the importance of education, and especially higher education, as an 'industry' of the future. There is an emerging understanding of the way in which higher education is now central to economic (post) modernisation and the key to competing successfully within the global economy. This understanding has emerged from the shifts that are purportedly taking place in the production and consumption of knowledge which are impacting on traditional knowledge institutions like universities (see Peters \& Roberts, 1999).

The role of the university is undergoing a transition in late modernity as a result of structural shifts in the production and legitimation of knowledge. The older goal of the democratisation of the university has now been superseded by new challenges arising from the dual processes of the globalisation and fragmentation of knowledge cultures. These arise from a range of related developments: the separation of knowledge (research) from the postsovereign state that no longer exclusively supports Big Science; the rise of new regulatory regimes that impose an 'audit society' on the previously autonomous society; a separation of research from teaching (education); the decoupling of knowledge from society and the replacement of the public by target constituencies; the functional contradiction between science and economy in the increasing specialisation of knowledge and the decline in occupational opportunities; the de-territorialisation of knowledge as a result of new communication technologies and knowledge flows; the crisis of scientific rationality under conditions of the 'risk society', reflexivity and the new demands for the legitimation of knowledge (see Delanty,1998; see also, Fuller, 2000).

\section{CONCLUSION: UNIVERSITIES AND KNOWLEDGE CULTURES}

Readings asks how we might re-imagine the university once we have had to relinquish the notion of culture as the unifying idea. He argues that we should not embrace the techno-bureaucratic ideal of the corporate university. He argues further that we should attempt to live in the ruins of the university without romance or nostalgia. Since Kant the university has operated as a privileged model of free and 
rational discussion, one, based upon a notion of communication that ties the individual to the nation-state. Readings wants to critique this notion. He offers us a new community of dissensus as a model for the post-historical university: not one based upon consensus and transparency but rather upon openness, opaqueness, incompleteness and difference.

I have great sympathy for Readings' view. It is one that I have myself argued for elsewhere. Rather than explore the underlying notion of community at stake -- its political dimensions and exclusions -- I want to take a different tack and suggest a form of the university that does not break entirely with the founding historical discourses and their single unifying ideas but preserves them, adapts them to new conditions, reinvents and redefines them as an imaginative basis for resistance against the narrowing of thought.

Universities, traditionally, have been concerned principally with two main functions: research or the production of knowledge, and teaching or its dissemination and acquisition. Universities are, and have been historically, the central knowledge institutions of the modern state, although, significantly, they pre-date the development of the nation-state. Knowledge has been seen not only as an end in itself but also as an essential and defining element of the Western tradition, closely tied to scientific and material progress, cultural preservation, and the nature of both the market and democracy. The knowledge functions of the university, especially since the time of Kant, have also carried a critical function, together with certain privileges and responsibilities, built up over many generations. Accordingly, the university has served as the critic and conscience of society and the critical function has been protected from political interference and the vagaries of the market through the historical development of notions of institutional autonomy and academic freedom. This has been the essence of the idea of the liberal university. In an important sense, the liberal university epitomised the idea of a public institution designed to serve the needs of society through the development of knowledge as a public good where knowledge, especially during the Enlightenment, was tied not only to scientific progress but also general emancipation. It was the exemplar of a public discursive space where knowledge could be 
pursued in a disinterested and scholarly fashion and ideas could be exchanged freely on the basis of academic interests. Today this ideal is undergoing radical change: in short, as the knowledge functions have become even more important economically, external pressures and forces have seriously impinged upon its structural protections and traditional freedoms. These shifts are most transparent in the discourse of the knowledge economy where traditional liberal values associated with knowledge-not only 'free inquiry', 'the freedom of thought' as an element of academic freedom, and 'liberation' and 'emancipation', but also the democratic virtues that are under girded by a notion of freedom - often come into conflict and suffer in decision trade-offs with values of utility, technical control, commercial secrecy and wealth creation.

The discourse on knowledge admits of different distinctions, which under conditions of knowledge capitalism may permit some variation at both the regional and institutional levels at least insofar as knowledge capitalism can be approached through different models: 'imperialistic' neo-liberal Anglo-American capitalism (the so-called 'Washington Consensus' issuing in structural adjustment policies), capitalism of Blair's Third Way that emphasises new 'public/private' synergies, French state capitalism, Scandinavian welfare capitalism, Rhine capitalism, Japanese corporatist capitalism, Chinese post-socialist capitalism. Each regional model will emphasise a different approach to conceiving higher education in the knowledge economy that may depend heavily on cultural factors such as learning traditions. The importance of regional models of the knowledge capitalism has not yet been studied or unpicked.

The discourses of the knowledge economy points to the new insights flowing from the economics of knowledge, the economics of information and the economics of education, whereas the concept of the 'knowledge society' helps to elucidate the concepts and rights of knowledge workers as citizens in the new economy, focusing on the subordination of economic means to social ends. In the former neoclassical economics and the revival of homo economicus brings together the ancient problematic of knowledge (that pre-dates capitalism and feudalism and dates from the first organised academies in classical Greece), with the problematic of capitalism 
that is less than a thousand years old and only recently (since WWII) a disciplinary formation or field. In the latter, the concept highlights the juridical and legal infrastructure that must accompany knowledge capitalism - knowledge and information rights of the citizen, not only rights of access to knowledge, education rights per se, and the rights of open and free information-a foundation of the free society-but also intellectual property rights (e.g., patents, copyright), the knowledge rights of the knowledge worker (human capital rights), and democratic rights concerning the governance of public science.

I argue that we should accommodate the term 'knowledge cultures' as it is crucial for understanding questions concerning the development of both knowledge economies and knowledge societies. The term points to the cultural preconditions that must be established before economies or societies based on knowledge can be properly understood or established. Knowledge cultures are based on shared epistemic practices, they embody culturally preferred ways of doing things, often developed over many generations. Simplified in the extreme, my argument would be that knowledge production and dissemination requires the exchange of ideas and such exchanges, in turn, depend upon certain cultural conditions, including trust, reciprocal rights and responsibilities between different knowledge partners, institutional regimes and strategies (a form of institutional knowledge socialism?). I use the term 'knowledge cultures' (in the plural) because there is not one prescription or formula that fits all institutions, societies or knowledge traditions.

If we were to admit this notion we could, perhaps, move from a single unifying idea to a constellation or field of overlapping and mutually self-reinforcing ideas of the liberal university. First, a preservation of the Kantian University and the Idea of Reason where Kant's critical philosophy or critical reason as a source of criticism, critique and reflection - pointed us moderns towards the continuing relevance of the ideals of self-criticism, self-reflection and selfgovernance. As Michel Foucault (1996: 312) put it so well:

the thread which may connect us to the Enlightenment is not faithfulness to doctrinal elements but, rather, the permanent 
CHAPTER 11

reactivation of an attitude -- that is, of a philosophical ethos that could be described as a permanent critique of our historical era.

Second, the Humboldtian University and the Idea of Culture, although modulated differently can be reconstructed in two senses: from Bildung as self-cultivation and moral self-formation to learning processes (pedagogy) based on an ethical relation of self and other; and from national culture to cultural self-understandings and cultural reproduction which implies a recognition of indigenous cultures and traditional knowledges, an awareness of 'nation' as a socio-historical construction, and an acceptance of the reality of multiculturalism. Third, the University of Literary Culture (Newman-Arnold-Leavis) is understood where a national culture as a predominantly literary culture is revealed in the tradition of a national literature or canon. Crucial here is the shift from a literary to post-literary culture: the modern western university was a print culture shaped by print technologies for the creation, storage and transmission of knowledge. The shift to new techno-cultures is being shaped by digital technologies for the storage and exchange of information. We must begin to understand the new techno-cultures in relation to the university where the radical concordance of image, text and sound sets up new exigencies and promises for pedagogy but also new dangers. If we were to embody these new imaginings that reconnect us to the threads of the modern university we may be able to encompass and redirect the energies of the Corporate 'Massified' Service University towards the democratic possibilities and impulses of the historic shift from cultural élite formation to genuine mass access and democratic participation. 
HIGHER EDUCATION, GLOBALISATION AND THE KNOWLEDGE ECONOMY

Figure 1

The Dearing Report:

Main Causes

Globalisation as World Economic Integration

- $\quad$ technological changes in telecomunications, information and transport

- $\quad$ the (political) promotion of free trade and the reduction in trade protection

Main Elements

- $\quad$ the organisation of production on a global scale

- the acquisition of inputs and services from around the world which reduces costs

- the formation of cross-border alliances and ventures, enabling companies to combine assets, share their costs and penetrate new markets

- $\quad$ intergation of world capital markets

- availability of information on international benchmarking of commercial performance

- $\quad$ better consumer knowledge and more spending power, hence, more discriminating choices

- $\quad$ greater competition from outside the established industrial centres

Consequences for the Labour Market

- $\quad$ downward pressure on pay, particularly for unskilled labour

- $\quad$ upward pressure on the quality of labour input

- $\quad$ competition is increasingly based on quality rather than price

- $\quad$ people and ideas assume greater significance in economic success because they are less mobile than other investments such as capital, information and technology

- $\quad$ unemployment rates of unskilled workers relative to skilled workers have increased

- more, probably smaller, companies whose business is knowledge and ways of handling knowledge and information are needed

Implications for Higher Education

- $\quad$ high quality, relevant higher education provision will be a key factor in attracting and anchoring the operations of global corporations

- $\quad$ institutions will need to be at the forefront in offering opportunities for lifelong learning

- $\quad$ institutions will need to meet the aspirations of individuals to re-equip themselves for a succession of jobs over a working lifetime

- $\quad$ higher education must continue to provide a steady stream of technically skilled people to meet needs of global corporations

- $\quad$ higher education will become a global service and tradeable commodity

- $\quad$ higher education institutions, organisationally, may need to emulate private sector enterprises in order to flourish in a fast-changing global economy

- $\quad$ the new economic order will place a premium on knowledge and institutions, therefore, will need to recognise the knowledge, skills and understanding which individuals can use as a basis to secure further knowledge and skills

- $\quad$ the development of a research base to provide new knowledge, understanding and ideas to attract high technology companies

Source: Compiled from the Dearing Report, 'The Wider Context', 1997. http://www.leeds.ac.uk/niche/index.htm

\section{Author's Bio:}


Michael A. Peters is professor of education at the University of Illinois at Urbana-Champaign and the University of Glasgow. He is the executive editor of 'Educational Philosophy and Theory' and editor of two international ejournals, 'Policy Futures in Education' and 'E-Learning'. His interests are in education, philosophy and social policy and he has written over thirty-five books, three hundred articles and chapters, including most recently 'Why Foucault? New Directions in Educational Research' (Peter Lang, 2007), 'Building Knowledge Cultures: Educational and Development in the Age of Knowledge Capitalism' (Rowman \& Littlefield, 2006), both with Tina (A.C.) Besley, and ' Development and the Future of the University' (Sense, 2007).

Ubiquity Volume 8, Issue 18 (May 7, 2007 - May 14, 2007)

NOTES

NOTES

1 This chapter is based on a lecture originally presented in the Winter Lectures series, The University in the 21st Century, Maidment Theatre, The University of Auckland, 25 August 1998. A shorter version appears in

2 Pleasing features of the White Paper include the intention to establish a new Arts and Humanities Research Council, the emphasis on fair access and closing the social class gap, and the recognition of the importance of high quality teaching.

3 Both Lyotard and Readings exercised a strong direction over my thought and both have been generous in their encouragement to me and supportive of my work. Lyotard (1995) wrote the Foreword to the collection I edited, Education and the Postmodern Condition (1995), to which Readings (1995) contributed the final chapter. Readings invited me in 1994 to give a paper (see Peters, 1996) at his multidisciplinary seminar at the Université de Montreal called 'L'Université et la Culture: La Crise Identitaire d'une Institution' upon which he book was based. He died in an air accident on October 31, 1994.

4 For a history of the trope of ruins and modernity's preoccupation with 'the primordial unity and immediacy of a lost origin' see Readings (1996: 169). 
5 See also Smith \& Webster's (1997) The Postmodern University? Contested Visions of Higher Education in Society and Crittenden's (1997) 'Minding Their Business'.

6 He says in a now famous formulation:

I will use the term modern to designate any science that legitimates itself with reference to a metadiscourse. . . making explicit appeal to some grand narrative, such as the dialectics of Spirit, the hermeneutics of meaning, the emancipation of the rational or working subject, or the creation of wealth (Lyotard, 1984: xxii).

By contrast, he defines postmodern simply as 'incredulity toward metanarratives' (Lyotard, 1984: xxiv).

7 The speculative narrative of the unity of all knowledge held that knowledge is worthy of its name only if it can generate a second-order discourse that functions to legitimate it, otherwise such 'knowledge' would amount to mere ideology. The process of 'delegitimation' has revealed that not only does science play its own language game (and consequently is both on a par with and incapable of legitimating other language games) but also it is incapable of legitimating itself as speculation assumed it could.

8 By European cultural disintegration Lyotard is referring, first, to the collapse of the monarchies and the two world wars, and, second, what Friedrich Nietzsche calls the question of European nihilism.

9 The developments described here under the banner of globalisation which accentuate the primacy of knowledge, are further underwritten by recent advances in so-called 'growth theory'. Neoclassical economics does not specify how knowledge accumulation occurs. As a result there is no mention of human capital and there is no direct role for education. Further, in the neoclassical model there is no income 'left over' (all output is paid to either capital or labor) to act as a reward or incentive for knowledge accumulation. Accordingly, there are no externalities to knowledge accumulation. By contrast, new growth theory has highlighted the role of education in the creation of human capital and in the production of new knowledge. On this basis it has explored the possibilities of educationrelated externalities. In short, while the evidence is far from conclusive at this stage there is a consensus emerging that education is important for successful research activities (e.g., by producing scientists and engineers), which are, in turn, important for productivity growth and; education creates human capital, which directly affects knowledge accumulation) and therefore productivity growth (see Report 8, ‘Externalities in Higher Education', Dearing, 1997.

10 See Peters (2002). 